\title{
Antiviral properties of essential oils of Foeniculum vulgare and Pimpinella anisum L.
}

\author{
H.S. Shukla, P. Dubey and R.V. Chaturvedi \\ Department of Botany, University of Gorakhpur, Gorakhpur 273009, India \\ (received 7-8-1987, accepted 12-12-1988)
}

Summary - The antiviral activity of the essential oils of Foeniculum vulgare Mill. and Pimpinella anisum $\mathrm{L}$. has been tested against PVX (potato virus X), TMV (tobacco mosaic virus) and TRSV (tobacco ring spot virus) on the hypersensitive host Chenopodium amaranticolor. Both the essential oils totally inhibit the formation of local lesions at a concentration of $3000 \mathrm{ppm}$.

antiviral activity - essential oils - phenols

Résumé - Les propriétés antivirales des huiles essentielles de Foeniculum vulgare et Pimpinella anisum L. L'activité antivirale des huiles essentielles de Foeniculum vulgare Mill. et Pimpinella anisum L. a été éprouvée quant à l'installation du PVX (virus $x$ de la pomme de terre), TMV (virus de la mosaïque du tabac) et TRSV (virus des taches annulaires du tabac) sur un hôte hypersensible, Chenopodium amaranticolor. Les deux huiles essentielles inhibent totalement la formation de lésions locales à la concentration de $3000 \mathrm{ppm}$.

activité antivirale - huiles essentielles - phénols

\section{Introduction}

Green plants contain a reservoir of chemicals with unique biological activity (Farnsworth \& Bingel, 1977). Essential oils extracted from higher plants have been extensively studied for their fungitoxic (Shukla \& Tripathi, $1987 \mathrm{a}, \mathrm{b}$ ), bactericidal (Narayan et al., 1980) and insecticidal properties (Beye, 1978). Unfortunately such useful compounds have seldom been tested for their antiviral properties (Shukla et al., 1985; Rao et al., 1986). This study has therefore been undertaken with the view to examining the inhibitory activity of essential oils of Foeniculum vulgare and Pimpinella anisum against PVX, TMV and TRSV.

\section{Materials and Methods}

The cultures of different viruses, i.e. PVX, TMV, and TRSV were obtained from the National Botanical Research institute, Lucknow, and maintained separately on the young plants of Nicotiana tabacum $\mathrm{L}$. var. Turkish in a insect-proof glasshouse.
In order to extract the volatile constituents (essential oils), the fruits of Foeniculum vulgare Mill. and Pimpinella anisum L. were obtained from local stockists and subjected to hydrodistillation on Clevenger's apparatus (Clevenger, 1928). The essential oils were collected in the form of a water immiscible oil.

Standard inoculum of each virus, used as infective sap for inoculation in the present study, was prepared by macerating Nicotiana tabacum virus-infected leaves of the same age separately, with neutral phosphate buffer $(\mathrm{pH} 7.0,0.1 \mathrm{M} ; 1 \mathrm{ml} / \mathrm{g}$ of leaf material), squeezing the crude extract through layers of muslin cloth and filtrate was centrifuged at $3000 \mathrm{~g}$ for $15 \mathrm{~min}$. The supernatant was taken as standard inoculum for each assay.

Requisite quantities of each essential oil was added to $5 \%$ aqueous sterilized solution of acetone in order to get final concentrations of $1000 \mathrm{ppm}, 2000 \mathrm{ppm}$ and $3000 \mathrm{ppm}$ of the oils separately after mixing the standard inoculum $(1: 1)$. For control standard inoculum and $5 \%$ aqueous sterilized solution of acetone (1:1) was used. The mixture of standard inoculum and inhibitor was vigorously shaken for $30 \mathrm{~min}$ and kept for another 30 min before inoculation in 20 healthy leaves of Chenopodium amaranticolor Costt et Reyn of the same age group, hypersensitive local lesion host, in randomised latin square pattern (Rao et al., 1986). Each experiment had 5 replicates. The observations 
were recorded on the seventh day, and the percentage inhibition of viruses was calculated using the following formula:

Percentage inhibition of virus $=[\mathrm{C}-\mathrm{T} / \mathrm{C}] \times 100$.

Where: $\mathrm{C}=$ No. of lesions on control leaves; $T=$ No. of lesions on treated leaves.

The data were statistically analysed by test of comparison between the control and individual treatment sets (Shukla et al., 1985).

\section{Results and discussion}

As is clear from table I, the essential oils of $F$. vulgare and $P$. anisum at $3000 \mathrm{ppm}$ completely inhibited PVX, TMV, and TRSV infection. However, at $2000 \mathrm{ppm}$ and $1000 \mathrm{ppm}$ these oils only partially inhibited the infection (see also Table I).

The inhibition of plant viruses by chemicals was first tested by Allard (1914), and since then a large number of chemicals of plant origin, i.e. proteins, glycoproteins, colloidals of higher molecular weight, phenolic tanins, etc., have been reported to possess antiviral activity (Bawden, 1954; Verma, 1973).

The oils of Foeniculum vulgare and Pimpinella anisum exhibited the presence of phenols (Shukla \& Tripathi, 1987a, b). The inhibitory effect of these oils might be due to the presence of phenols in them, which are already known to be potent inhibitors of plant viruses (Joshi \& Prakash, 1981). These phenols interact with virions in vitro, resulting in the loss of virus infectivity (Muftuoglu \& Nienhans, 1976). The inhibitory effects of phenols present in these essential oils is also probably due to their effect on host susceptibility by blocking the infection sites on the leaf surface (Verma, 1973).

Further work on the isolation of active antiviral compound of the oil is in progress. These natural products will be useful in limiting the propagation of these viruses and should become a good source of plant protectant. Nevertheless, the use of these oils at a commercial level must await the results of large-scale trials and the examination of application modalities.

\section{Acknowledgments}

The authors are grateful to the Head of the Dept. of Botany, University of Gorakhpur, Gorakhpur, for providing laboratory facilities; UGC (New Delhi) for financial assistance and Prof. R.S. Tripathi, Dept. of English, GPU, for the French translation.

\section{References}

Allard H.A. (1914) The mosaic disease of tobacco. US Dep. gric. Farmer's Bull. 40, 33

Bawden F.C. (1954) Inhibitors and plant viruses. Adv. Virus Res. 2, 31-57

Beye F. (1978) Insecticides from the vegetable kingdom. Plant Res. Dev. 7, 13-31

Clevenger J.F. (1928) Apparatus for determination of volatile oils. J. am. Pharm. Assoc. 17, 346

Farnsworth N.R. \& Bingel A.S. (1977) Natural Products and Plant Drugs with Pharmacological, Biological or Therapeutic Activity (Waghen H. \& Wolf P., eds.), Springer-Verlag, Berlin

Joshi R.D. \& Prakash J. (1981) Phenolics as inhibitor of plant viruses. Adv. Front. Mycol. Plant Pathol. 265279

Muftuoglu T. \& Nienhans (1976) Virus inhibition in stone fruit plants. Phytopathol. Z. 85, 49-64

Narayan V., Rao, K.K. \& Girdhar R. (1980) Antibacterial activity of the essential oils of Cinnamomum zeylanicum. Indian Drugs 17 (11), 360-362

Rao G.P., Pandey A.K. \& Shukla K. (1986) Essential oils of some higher plants vis-à-vis some legume viruses. Indian Perf. 30 (4), 483-486

Shukla H.S., Rao G.P. \& Tripathi S.C. (1985) Reduction in PVX and PVY infectivity by volatile constituents. Anal. Edafol. Agrobiol., 44 (11-12) 1763-1766

Table I. Effect of essential oils of $F$. vulgare and $P$. anisum on infectivity of PVX, TMV and TRSV.

\begin{tabular}{lcccc}
\hline Essential oils & $\begin{array}{c}\text { Concentration } \\
(\mathrm{ppm})\end{array}$ & \multicolumn{3}{c}{ Percent inhibition of virus $^{*}$} \\
\cline { 4 - 5 } & & $P V X$ & $T M V$ & $T R S V$ \\
\hline Foeniculum vulgare & 1000 & 46.66 & 46.66 & $53.33^{\mathrm{a}}$ \\
& 2000 & $76.00^{\mathrm{a}}$ & $78.66^{\mathrm{a}}$ & $80.00^{\mathrm{a}}$ \\
& 3000 & $100^{\mathrm{a}}$ & $100^{\mathrm{a}}$ & $100^{\mathrm{a}}$ \\
Pimpinella anisum & & $73.33^{\mathrm{a}}$ & $66.66^{\mathrm{a}}$ & $60.00^{\mathrm{a}}$ \\
& 1000 & $86.66^{\mathrm{a}}$ & $76.00^{\mathrm{a}}$ & $80.00^{\mathrm{a}}$ \\
& 2000 & $100^{\mathrm{a}}$ & $100 \mathrm{a}$ & $100^{\mathrm{a}}$
\end{tabular}

* : Average on 20 leaves of Chenopodium amaranticolor.

a : Difference due to treatment with oils are significant at $1 \%$ level. 
Shukla H.S. \& Tripathi S.C. (1987a) Studies on physicochemical, phytotoxic and fungitoxic properties of essential oil of Foeniculum vulgare Mill. Beitr. Biol. Pflanz. 62, 149-158

Shukla H.S. \& Tripathi S.C. (1987b) Antifunga substan$\mathrm{ce}$ in the essential oil of anise (Pimpinella anisum L.)
Agric. Biol. Chem. 51, 1991-1993

Verma V.S. (1973) Study on the effect of flavonoids on the infectivity of potato virus $X$. Zentralbl. Bakteriol. Parasitenkd. Infektionskr. Hyg. Zweite Abt. 128 S/ 467472 